\title{
Preweaning dairy calves' preferences for outdoor access
}

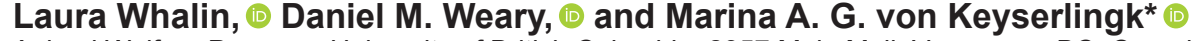 \\ Animal Welfare Program, University of British Columbia, 2357 Main Mall, Vancouver, BC, Canada, V6T $1 Z 4$
}

\begin{abstract}
Adult dairy cattle show a preference for outdoor spaces during summer nights, but little is known about such preferences for dairy calves. Our aim was to determine the preferences of dairy calves for outdoor access during their first 11 wk of age in summer conditions. Calves were paired $(\mathrm{n}=10)$ at $7 \mathrm{~d}$ of age and placed in one of 10 pens $(7.32 \times 2.44 \mathrm{~m}$, deep bedded with bark mulch), each with equally sized outdoor and indoor areas. All feed was provided indoors; calves had ad libitum access to water, hay and concentrate. During the preweaning period, from 5 to $29 \mathrm{~d}$ of age, calves were offered $12 \mathrm{~L} / \mathrm{d}$ of milk divided into 2 feedings. Calves were weaned stepwise, with milk gradually reduced by 1 $\mathrm{L} / \mathrm{d}$ from d 30 to 35 of age. Calves were fed $6 \mathrm{~L} / \mathrm{d}$ from 35 to $51 \mathrm{~d}$ of age, then milk was again reduced by $1 \mathrm{~L} / \mathrm{d}$ so that calves were completely weaned by $56 \mathrm{~d}$ of age. Calves remained in the trial until, on average $( \pm S D)$, $72 \pm 2 \mathrm{~d}$ of age. Pens were continuously video recorded, and behaviors were scored $3 \mathrm{~d} /$ wk using 5-min scan samples. Four observers scored whether calves were inside, outside, lying, standing, in the sun or shade (interobserver reliability $=0.97$ ). Sun and shade could not always be detected, so a proportion was calculated as the amount of time in the sun or shade divided by the total time sun or shade was visible. Calves spent approximately one-third of their time outside throughout the experiment, and time spent outside was affected by several factors. Pairs of calves spent less time outside as the amount of rain increased. During the first $6 \mathrm{wk}$ of age, time spent outside increased, but time spent outside decreased between wk 6 and 7 , and remained around $200 \mathrm{~min} / \mathrm{d}$ from wk 7 to 11 . Calves with the highest average daily gain and calves that were approximately $50 \%$ white appeared to spend more time outdoors. When outside, calves spent similar amounts of time in the sun and shade during the first $8 \mathrm{wk}$,
\end{abstract}

Received July 26, 2021.

Accepted October 18, 2021.

*Corresponding author: nina@mail.ubc.ca but after weaning they appeared to spend more time in the shade. When calves were outside they appeared to spend a greater proportion of their time standing than when they were indoors during the first $4 \mathrm{wk}$. These results indicate that, when given the option in the summer, calves make use of an outdoor space, but this appears to vary with weather, calf age, average daily gain, and coat color.

Key words: animal welfare, behavior, natural living, calf housing

\section{INTRODUCTION}

When introduced to farm animal management systems, the public frequently raise concerns regarding naturalness, reflecting their desire that animals be provided reasonably natural environments with space and ability to engage in species-specific behaviors $(\mathrm{Te}$ Velde et al., 2002; Lassen et al., 2006). For example, many people place a value on the ability of an animal to engage in natural behaviors such as exploration, socialization, and foraging (Vanhonacker et al., 2008). Similarly, outdoor access and sufficient space have been described as desirable features for rearing cows and pigs (Cardoso et al., 2016; Sato et al., 2017), and at least some pasture access for cows is considered particularly important (Schuppli et al., 2014; Hötzel et al., 2017).

Biological research has also shown that cows can benefit from pasture access (as reviewed by Charlton and Rutter, 2017; Smid et al., 2020), and that cows have a partial preference for outdoor access depending time of day and environmental conditions. For example, when provided the choice between indoor and outdoor access in good summer weather, cows generally prefer to be on pasture at night and prefer to stay inside during the day (Legrand et al., 2009). However, little research to date has assessed outdoor access for dairy calves. Much recent research on dairy calf housing has focused on the effects of providing social companions. This work has shown, for example, that socially housed calves display evidence of improved cognitive development (Gaillard et al., 2014; Meagher et al., 2015; Broucek et al., 2021), perform more play (Duve et al., 2012), and are less 
reactive to novelty (Jensen et al., 1997; De Paula Vieira et al., 2012; Costa et al., 2014) compared with individually housed calves.

Studies exploring the physical features calves use have often focused on artificial enrichments to redirect oral behaviors and grooming (Pempek et al., 2017; Zobel et al., 2017). Understanding the importance of natural features, such as outdoor access, is now warranted. When raised on pasture with a herd, calves have access to a complex physical environment with space to explore, different forages, varying topography and soil types, changing climatic conditions and shade sources (Dwyer, 1961; Hutchison et al., 1962; Kilgour et al., 2012). Several studies have described diurnal behavior patterns in these natural systems including the times when calves play (Dwyer, 1961; Reinhardt and Reinhardt, 1981), suckle (Hutchison et al., 1962; Reinhardt and Reinhardt, 1981; Vitale et al., 1986), and graze (Kilgour et al., 2012; Martins et al., 2017). For example, in natural systems calves reduce time spent lying with age (Hutchison et al., 1962; Vitale et al., 1986; Kerr and Wood-Gush, 1987), perhaps because they spend more time grazing (Chambers, 1959; Dwyer, 1961; Hutchison et al., 1962). Similar to adult animals (Schütz et al., 2010; Charlton et al., 2011a; Smid et al., 2019), weather may also affect calf behavior when outdoors. For example, calves continue to graze in rain unless there is a heavy storm (Chambers, 1959), but little is known about the effects of temperature, humidity, and wind on a calf's preference for the outdoors.

Preference tests ask animals to choose between at least 2 options, but are dependent on context, previous experiences and time of testing (reviewed by Kirkden and Pajor, 2006). Several studies focusing on cow preference for outdoor spaces gave the animals a short time (e.g., 2 d) to habituate to the options, or only followed the animals for a week (Charlton et al., 2011a; Smid et al., 2018, 2019), which may not have captured a variety of environmental conditions. As calves shift their time spent engaging in some behaviors with age (Hutchison et al., 1962; Vitale et al., 1986; Kerr and Wood-Gush, 1987), perhaps their preferences regarding an outdoor space change with age. The aim of this study was to determine the preferences of dairy calves for outdoor access during their first 11 wk of age in summer conditions. We predicted that calves would show a partial preference for the outdoors, dependent upon time of day, and weather conditions (i.e., rainfall). We predicted that calves would not go outdoors when it was raining, and spend less time outdoors during the day. A secondary aim of the study was to describe the behavioral development of calves when given outdoor access. We predicted that calves would rest indoors, and that calves would spend more time outdoors as they grew older and encountered weaning.

\section{MATERIALS AND METHODS}

This study took place from the last week of May to the first week of September 2019, at The University of British Columbia Dairy Education and Research Centre (BC, Canada). All procedures were approved by the UBC Animal Ethics committee under protocol \#A18-0198. This was a descriptive study, and no sample size was calculated.

\section{Housing and Animal Management}

Within $6 \mathrm{~h}$ after birth, Holstein heifer calves were removed from their dam, weighed (birth weight: mean $\pm \mathrm{SD}=39.9 \pm 4.1 \mathrm{~kg}$; range $=31.0-47.0 \mathrm{~kg}$ ), fed $4 \mathrm{~L}$ of colostrum, and moved to an individual sawdust bedded pen. Twenty-four hours after birth, one trained observer gently restrained the calf with the head elevated and turned to the side, and a second trained observer collected 5 to $10 \mathrm{~mL}$ of blood from the jugular vein with a vacutainer needle. Blood samples were then analyzed using a Reichert AR 200 Digital Hand-Held Refractometer (Reichert) to ensure all calves had serum total proteins above $5.5 \mathrm{~g} / \mathrm{dL}$ to be included in the study. At $6 \pm 1 \mathrm{~d}$ of age calves underwent a health check and those deemed healthy were enrolled in the study and randomly assigned to their experimental pen. Only one heifer calf born during this time was not included in the study due to low serum total proteins. A total of 20 healthy calves were enrolled in the study and paired chronologically by birthdate. Due to intervals between births, calves were paired at $7 \pm 2 \mathrm{~d}$ of age. In this pen (Figure 1) calves had free access to an outdoor space $(3.66 \times 2.44 \mathrm{~m})$ and an adjoining indoor space $(3.66 \times$ $2.44 \mathrm{~m}$ ), so that they had a rectangular pen, half in the barn and half outdoors $(7.32 \times 2.44 \mathrm{~m})$. The entire pen was bedded with bark mulch. Three sides of the pen were solid so that pairs of calves had no visual access to other pairs, and one side of the pen was open fencing, facing outside. Pens were cleaned daily.

Calves were offered $12 \mathrm{~L}$ of whole milk divided into 2 feedings/d $(0800,1800 \mathrm{~h}$ ) from 5 to $29 \mathrm{~d}$ of age (preweaning period). Two nipples were fixed to the inside wall that could also be used as a pen opening $(76 \mathrm{~cm}$ from the ground, spaced $122 \mathrm{~cm}$ apart; see Figure 1) of each pen. One end of a hose was affixed to each nipple, and the other end of the hose was placed in a bucket of milk. Nipples were cleaned once per day, and hoses and buckets were cleaned twice per day. Calves were weaned stepwise; from d 30 to 35 of age the amount of 


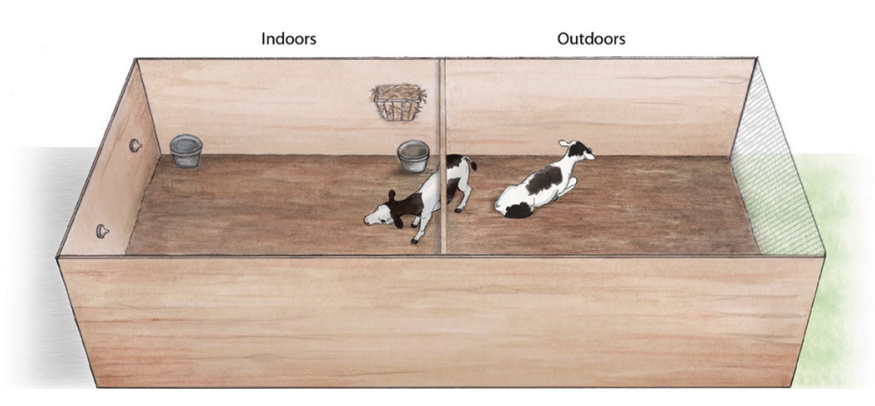

Figure 1. Pairs of calves $(n=10)$ had free access to a rectangular pen $(7.32 \times 2.44 \mathrm{~m})$, half in the barn and half outdoors. The entire pen was bedded with bark mulch. Three sides of the pen were solid, and 1 side of the pen was open fencing, facing outside. Milk from artificial teats, water, concentrate, and hay were provided indoors.

milk offered was reduced by $1 \mathrm{~L} / \mathrm{d}$. Calves were fed 6 $\mathrm{L} / \mathrm{d}$ from d 35 to 51 , then milk was again reduced by 1 L/d so that calves were completely weaned by d 56 of age (weaning period: $30-55 \mathrm{~d}$ of age). Calves remained in the trial until d 70 (postweaning period: $56-70 \mathrm{~d}$ of age). Throughout the trial, calves had ad libitum access to a calf starter $(20 \% \mathrm{CP}$ texturized starter; Richie Smith Feeds, Inc.), water and hay (a local blend of tall fescue, orchard grass and ryegrass). Hay and concentrates were placed near the division between the indoor and outdoor parts of the pen; water was offered indoors.

Calves underwent health checks once per week using the Calf Health Scorer App (University of WisconsinMadison), as described by Renaud et al. (2018) and Wilson et al. (2020), examining the respiratory system (nose, eye, ear, cough; McGuirk and Peek, 2014), fecal consistency (McGuirk, 2008), navel inflammation (adapted from Fecteau et al., 1997), joint swelling, and rectal temperature on 4-point scales with the aid of standardized images and descriptions. We also performed daily visual examinations of all calves, and any calf appearing ill received a full examination as described above. Following our standard farm protocol, 9 calves were treated with electrolytic solutions (Hydrafeed, EXL Laboratories) and a nonsteroidal anti-inflammatory drug (meloxicam, $0.5 \mathrm{mg} / \mathrm{kg}$ of BW; Boehringer Ingelheim) due to poor appetite and diarrhea. Two calves were administered Resflor Gold (florfenicol and flunixin, $6 \mathrm{~mL} / 45 \mathrm{~kg}$, Intervet Inc.) due to navel inflammation, and a tongue injury, respectively. Finally, one calf experienced bloat and was treated with the antibacterial Trimidox (trimethoprim and sulfadoxine, $1 \mathrm{~mL} / 15 \mathrm{~kg}$; Vetoquinol N.-A. Inc.), as well as electrolytes and meloxicam. In total, 12 calves were recorded as receiving treatment for ill health. All calves were weighed once per week (Smart1 Scales, Westernscale Inc.) to capture average daily gain across the experimental period. Calf coat color was also assessed, where calves were recorded as majority white (n $=5)$, majority black $(\mathrm{n}=8)$, or approximately $50 \%$ of each color $(\mathrm{n}=7)$.

\section{Behavioral Measures}

Calf behavior and location within the pen were recorded using 2 digital cameras (WV-CW504SP, Panasonic) both positioned $5 \mathrm{~m}$ above the pen (one indoors and one outdoors). Infrared lights (BR38 red incandescent flood light, $100 \mathrm{~W}$; Globe Electric Co. Inc.) were placed adjacent to all cameras to facilitate night vision. Behaviors of interest included lying, standing and location. Three days $(24 \mathrm{~h}$ each) per week (30 d/pair), 4 observers used 5-min scan sampling to score each calf's behaviors using an ethogram (Table 1) after establishing high interobserver reliability (average kappa = 0.97). Two pairs were not video recorded during wk 11, as they completed the experiment at $70 \mathrm{~d}$ of age.

Table 1. Ethogram of behaviors scored using 5-min scan samples, with the behavior of each of calf ( $\mathrm{n}=20)$ scored $3 \mathrm{~d} /$ wk from 6 to $70 \mathrm{~d}$ of age; pairs of calves $(\mathrm{n}=10)$ were permitted free access to an outdoor space $(3.66 \times 2.44 \mathrm{~m})$ and an indoor space $(3.66 \times 2.44 \mathrm{~m})$

\begin{tabular}{|c|c|}
\hline Variable & Description \\
\hline \multicolumn{2}{|l|}{ Behavior } \\
\hline Standing & $\begin{array}{l}\text { An upright position. A calf may be on her knees, running, playing, walking, or standing with all } 4 \text { feet in contact with the } \\
\text { ground. }\end{array}$ \\
\hline Lying & $\begin{array}{l}\text { Lying with either the left or right side of the body in contract with the ground, or over half of the body is in contact with } \\
\text { the ground. }\end{array}$ \\
\hline \multicolumn{2}{|r|}{ 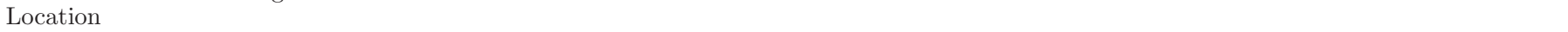 } \\
\hline Inside & Over half of the calf's body is inside the barn. The calf's head, shoulders, and 2 front feet constitute over half the body. \\
\hline Outside & Over half the body is outside. The calf's head, shoulders and 2 front feet constitute over half the body. \\
\hline \multicolumn{2}{|r|}{ 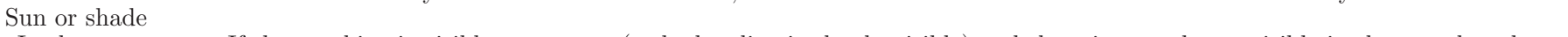 } \\
\hline In the sun & $\begin{array}{l}\text { If the sunshine is visible on camera (a shadow line is clearly visible) and there is enough sun visible in the pen that the } \\
\text { calf can stand with at least } 2 \text { feet in the sun. To be "in the sun," over half the calf's body must be in the sun. The calf's } \\
\text { head, shoulders, and } 2 \text { front feet constitute over half the body. }\end{array}$ \\
\hline In the shade & $\begin{array}{l}\text { If the sunshine is visible on camera (a shadow line is clearly visible) and there is enough sun visible in the pen that the } \\
\text { calf can stand with at least } 2 \text { feet in the sun. To be "in the shade," over half the calf's body must be in the shade. The } \\
\text { calf's head, shoulders and } 2 \text { front feet constitute over half the body. }\end{array}$ \\
\hline
\end{tabular}




\section{Climatic Measures}

Each day, hourly mean air temperature $\left({ }^{\circ} \mathrm{C}\right)$, maximum relative humidity (\%), mean wind speed $(\mathrm{km} / \mathrm{h})$, and total precipitation $(\mathrm{mm})$ were recorded by the Environment Canada weather station in Agassiz, located $400 \mathrm{~m}$ from The UBC Dairy Education and Research Centre. The temperature-humidity index (THI) was calculated as THI $=(1.8 \mathrm{~T}+32)-[(0.55-0.0055 \mathrm{RH})$ $\times(1.8 \mathrm{~T}-26)]$, where $\mathrm{T}=$ air temperature $\left({ }^{\circ} \mathrm{C}\right)$ and $\mathrm{RH}$ $=$ relative humidity (\%; Ravagnolo et al., 2000). Daily temperature, wind speed, and relative humidity averaged (mean $\pm \mathrm{SD}$ ): $18.2 \pm 2.5^{\circ} \mathrm{C}$ (range: $12.9-25.5^{\circ} \mathrm{C}$ ), $5.4 \pm 2.0 \mathrm{~km} / \mathrm{h}$ (range: $2.1-12.9 \mathrm{~km} / \mathrm{h}$ ), $72.8 \pm 9.3 \%$ (range: 49.6-90.7\%). Precipitation was recorded on 29 of the 103 experimental days and averaged $6.9 \pm 9.3$ $\mathrm{mm}$ (range: $0.2-43 \mathrm{~mm}$ ) on the days it rained. The THI averaged $63.2 \pm 3.4$ (range: $55.0-72.0$ ).

\section{Statistical Analysis}

All data were cleaned and visualized using $\mathrm{R}$ Studio (Version 1.4.1106 "Tiger Daylily"; (R Core Team, 2018) with tidyverse (Wickham et al., 2019), lubridate (Grolemund and Wickham, 2011), hms (Müller, 2021), janitor (Firke, 2021), plyr (Wickham, 2011), ggpubr (Kassambara, 2020), and writexl (Ooms, 2020). Descriptive statistics (mean $\pm \mathrm{SD}$ ) are provided for measures for which we did not have primary predictions (i.e., time spent lying, time spent in the sun or shade, ADG, and coat color). Time spent lying was summed by date and whether each calf was inside or outside. The proportion was then calculated by time spent lying divided by time spent in the inside or outside. This proportion was then averaged by pair, and finally calculated by period. Time spent in the sun or shade was similarly calculated. To cleanly visualize ADG at each wk of age with the raw data, the different growth rates were divided into 3 categories: calves gaining less than 1.0 $\mathrm{kg} / \mathrm{d}(0.8-0.9 \mathrm{~kg} / \mathrm{d} ; \mathrm{n}=7)$, gaining approximately 1.0 $\mathrm{kg} / \mathrm{d}(>0.9$ and $<1.1 \mathrm{~kg} / \mathrm{d} ; \mathrm{n}=6)$, and gaining over 1.0 $\mathrm{kg} / \mathrm{d}(1.1-1.2 \mathrm{~kg} / \mathrm{d} ; \mathrm{n}=7)$.

Inferential tests were conducted for our primary predictions using SAS (University Edition; SAS Institute Inc.). We ran 2 statistical models for our primary predictions with pair $(\mathrm{n}=10)$ as the experimental unit for both models (e.g., average time spent outside by pair), and all model residuals were visually assessed and were normally distributed. We first predicted that daily time spent outside would be affected by weather conditions, particularly rainfall. We averaged the total time each pair $(\mathrm{n}=10)$ spent outside per day. PROC UNIVARIATE was used to assess daily time spent outside for normality (normal distribution, no transformations needed), and following Smid et al. (2019) a Spearman correlation was used to investigate correlations between weather variables (i.e., daily rainfall, air temperature, THI, relative humidity, and wind speed). Air temperature and THI, as well as relative humidity and wind speed were highly correlated $(\mathrm{r}>0.7)$. We dropped air temperature and relative humidity as they were both captured in the THI measurement. The effects of the weather conditions (i.e., daily rainfall, THI, and wind speed) on the time spent outside were tested using PROC MIXED with day and pair included as random effects. The Satterthwaite method was used to estimate denominator degrees of freedom.

We also predicted that calves would spend less time outdoors during the day, and would spend more time outdoors as they grew older. Following the division of daytime and nighttime described in Smid et al. (2019), we summarized the time each pair spent outside by day (0600-2000 h) and night (2000-0600 h) each week. PROC UNIVARIATE was used to assess average time spent outside by day and night for normality. Using PROC MIXED and pair as the experimental unit $(\mathrm{n}=$ 10) we tested the effect of week of age on the outcome variable average time spent outside during the daytime and nighttime. Week was considered a repeated measure with an autoregressive covariance structure to account for the relationships between weeks. Due to differences in age when calves were paired, we did not include data from wk 1; wk 2 - 11 were included in our final model. Though statistical significance was declared for $P<0.05$, this study was inherently descriptive, and $P$ values are reported as a guide for future research. The means and standard errors reported below are derived from the model output (2 models).

The observer who did the primary data analysis approached this study with on-farm experience, and a deep appreciation for the welfare of each animal. The analysis and interpretation are inherently influenced by these values and the natural living component of animal welfare (Fraser et al., 1997).

\section{RESULTS}

\section{Factors Affecting Time Spent Outside}

Calves spent less time outside than inside before weaning (percent of each $24 \mathrm{~h}$, mean \pm SD: $32.6 \pm$ $15.0 \%$, range: $7.6-52.9 \%$ ), during weaning (34.2 \pm 9.1\%, range: $15.0-49.7 \%$ ), and after weaning (30.0 \pm $7.0 \%$, range: $17.6-38.8 \%$ ). Even at $7 \mathrm{~d}$ old, the first day calves were moved to the experimental pens they spent some time outside (16.4 $\pm 13.9 \%$, range: $2.5-50.3 \%)$. Time calves spent outside was affected by several factors. Pairs of calves spent less time outside (mean $\pm \mathrm{SE}$ : 


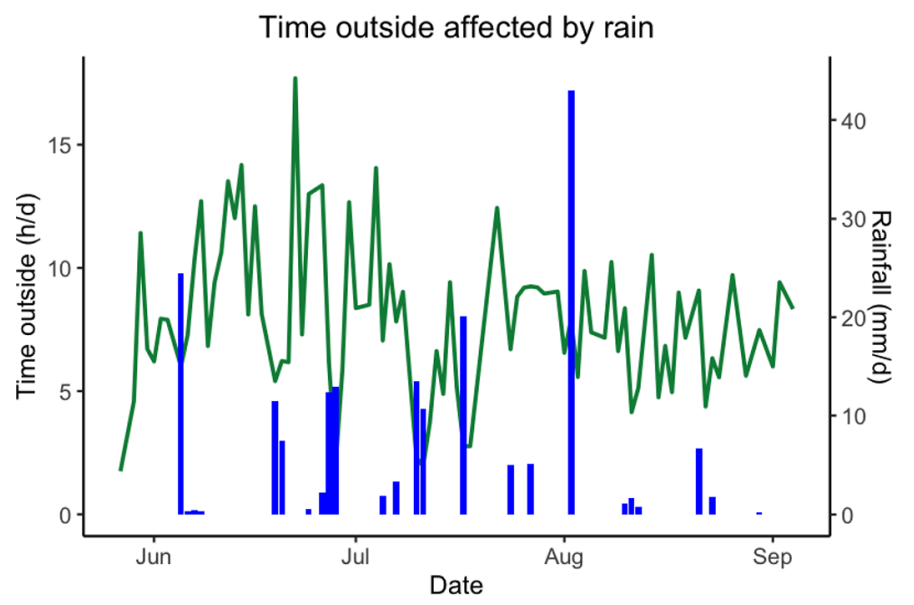

Figure 2. Total rain accumulation (blue bars; $\mathrm{mm} / \mathrm{d}$ ) and mean time pairs of calves $(\mathrm{n}=10)$ spent outside standing (green line) on each date of the trial when behaviors were scored. Calves spent less time outside as the amount of rain $(\mathrm{mm} / \mathrm{d})$ increased $(P<0.01)$. Pairs were permitted free access to an outdoor space $(3.66 \times 2.44 \mathrm{~m})$ and an indoor space $(3.66 \times 2.44 \mathrm{~m})$.

$-8.4 \pm 3.1 \mathrm{~min} /$ date $)$ as the amount of rain $(\mathrm{mm} / \mathrm{d})$ increased $\left(F_{1,74}=7.38, P<0.01\right.$; Figure 2$)$; daily THI $\left(F_{1,82.3}=0.03 ; P=0.87\right)$ and wind speed $\left(F_{1,89.6}=1.98\right.$, $P=0.16)$ had no effect on the time pairs spent outside.

Pairs of calves varied in the time spent outside throughout the experiment (range: $13.0-41.8 \%$ of their day spent outside), and appeared to have individual preferences. Pairs of calves made variable use of the outdoor space throughout a day, and patterns of outdoor use changed across the weaning periods (Figure 3 ). Time spent outside did not change with week of age during the night $\left(F_{9,79}=1.16, P=0.33\right.$; Figure 4$)$. During the day, there were differences in time spent outside each week $\left(F_{9,79}=2.10, P<0.04\right)$. During wk 2 calves spent $176.6 \pm 35.5 \mathrm{~min} / \mathrm{d}$ (mean $\pm \mathrm{SE}$ ) outside during the day. Calves increased their time spent outside during the day each week so that by wk 5 they were spending $298.9 \pm 35.5 \mathrm{~min} / \mathrm{d}$ outside, and wk 6 they spent $329.8 \pm 35.5 \mathrm{~min} / \mathrm{d}$ outside during the day. Between wk 6 and 7 calves decreased their time outside during the day, and from wk 7-11 calves were outside approximately $200 \mathrm{~min} / \mathrm{d}$ during the day (minimum: wk 10: $189.2 \pm 35.5 \mathrm{~min} / \mathrm{d}$ outside; maximum: wk 7 : $222.2 \pm 35.5 \mathrm{~min} / \mathrm{d}$ outside).

\section{Calf Level Factors}

Calves exited the trial at $72 \pm 2 \mathrm{~d}$ of age, with an average BW of $108.8 \pm 9.1 \mathrm{~kg}$ (91.5-128.5). Throughout the study calves gained on average $1.0 \pm 0.1 \mathrm{~kg} / \mathrm{d}$ $(0.8-1.2 \mathrm{~kg} / \mathrm{d})$. Calf growth may have contributed to variation in time spent outside each week (Figure 5).
Across the entire experiment, calves gaining less than $1.0 \mathrm{~kg} / \mathrm{d}(\mathrm{n}=7)$ spent on average $399.1 \pm 161.1 \mathrm{~min} / \mathrm{d}$ outside (range: 187.0-610.7 $\mathrm{min} / \mathrm{d}$ ). Similarly, calves gaining $1.0 \mathrm{~kg} / \mathrm{d}(\mathrm{n}=6)$ spent on average $428.3 \pm 57.7$ min/d outside (range: 350.7-505.2 min/d). However, calves with the highest average daily gain $(>1.0 \mathrm{~kg} / \mathrm{d}$, $\mathrm{n}=7)$ spent on average $569.8 \pm 84.3 \mathrm{~min} / \mathrm{d}$ outside (range: 411.8-666.9 $\mathrm{min} / \mathrm{d}$ ).

There was considerable variation, but calf color may also have contributed to variation in time spent outside each week. Calves that were mostly black $(\mathrm{n}=8)$ spent on average $411.2 \pm 156.2 \mathrm{~min} / \mathrm{d}$ (range: 187.0-610.7 $\mathrm{min} / \mathrm{d}$ ) outside across the experiment. Calves that were approximately $50 \%$ black $(\mathrm{n}=7)$ spent on average $524.6 \pm 109.8 \mathrm{~min} / \mathrm{d}$ outside (range: $377.4-666.9$ $\mathrm{min} / \mathrm{d})$. Calves that were mostly white $(\mathrm{n}=5)$ spent on
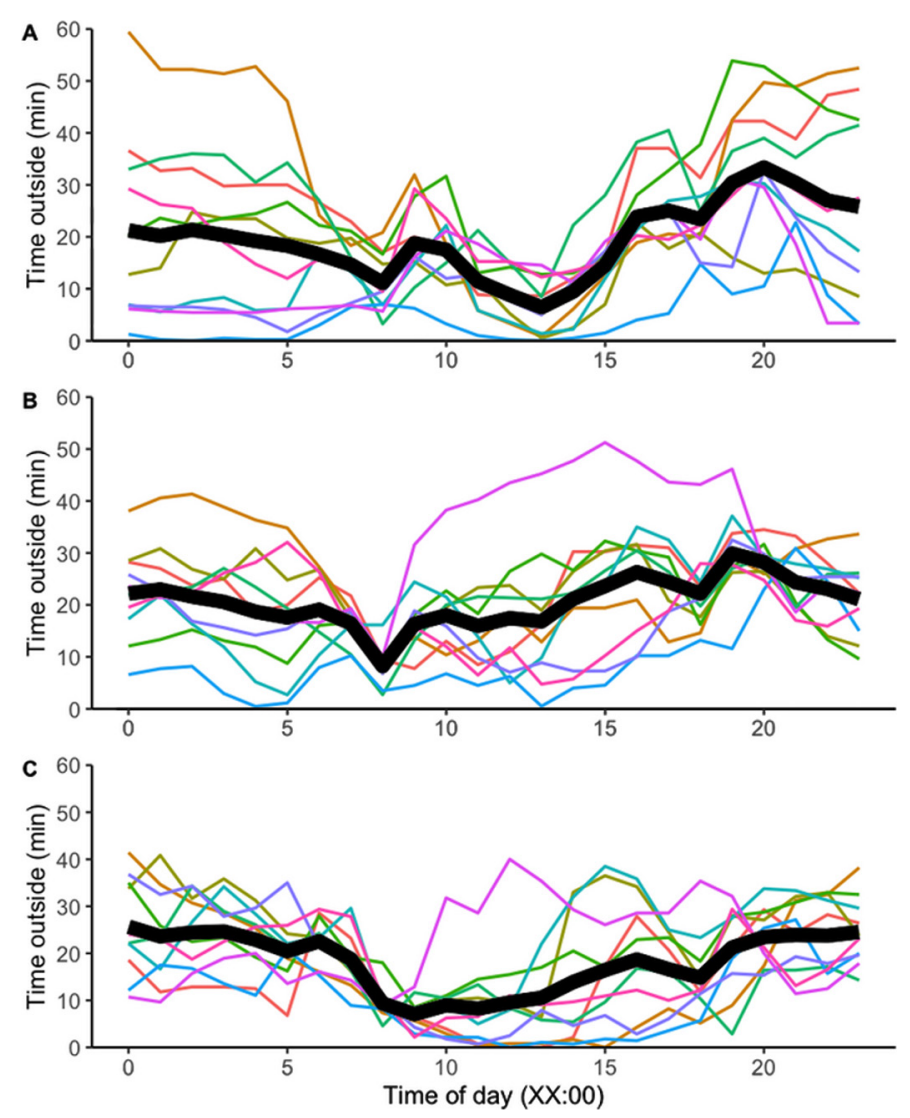

Figure 3. Pairs of calves $(\mathrm{n}=10)$ were permitted free access to an outdoor space $(3.66 \times 2.44 \mathrm{~m})$ and an indoor space $(3.66 \times 2.44 \mathrm{~m})$. Each nonblack line is the average time $(\min )$ a pair spent outside per hour of the day (averages from 5-min scan samples). The bold, black line is the average time all calves spent outside per hour of the day. Milk feeding took place at 0800 and $1800 \mathrm{~h}$. Patterns of outdoor use changed across the 3 weaning periods as follows: (A) preweaning (5-29 $\mathrm{d}$ of age: $8 \mathrm{~L} / \mathrm{d}),(\mathrm{B})$ weaning $(30-55 \mathrm{~d}$ of age: milk gradually reduced by $1 \mathrm{~L} / \mathrm{d}$ from d 30-35 so that calves were fed $6 \mathrm{~L} / \mathrm{d}$ until d 51 where milk was once again decreased by $1 \mathrm{~L} / \mathrm{d}$ for $5 \mathrm{~d}$ ), and (C) postweaning (56-70 d of age: $0 \mathrm{~L} / \mathrm{d})$. 
average $478.0 \pm 97.9 \mathrm{~min} / \mathrm{d}$ outside (range: $384.0-593.6$ $\min / \mathrm{d})$.

\section{Calf Behavior}

During the time that we could see both sun and shade on the video, we scored whether calves were in the shade. When outside, calves spent similar proportions of their time in the shade (versus in the sun) before weaning (mean \pm SD: $52.6 \pm 21.9 \%$, range: $19.8-85.1 \%)$ and during weaning $(50.8 \pm 21.4 \%$, range: 21.2-87.6\%), but after weaning calves began spending more time in the shade $(59.2 \pm 23.4 \%$, range: $28.4-$ $96.4 \%)$. In contrast, while indoors, calves spent most of their time in the shade during preweaning (94.2 \pm $4.5 \%$, range: $84.8-98.5 \%)$, weaning $(88.0 \pm 10.8 \%$, range: $68.1-97.1 \%)$, and postweaning $(81.8 \pm 13.9 \%$; range: 53.0 - $98.9 \%$ ) periods. When calves were outside during the preweaning period, they appeared to spend a greater proportion of their time standing than when they were using the indoor area but during both the weaning and postweaning periods calves spent a similar

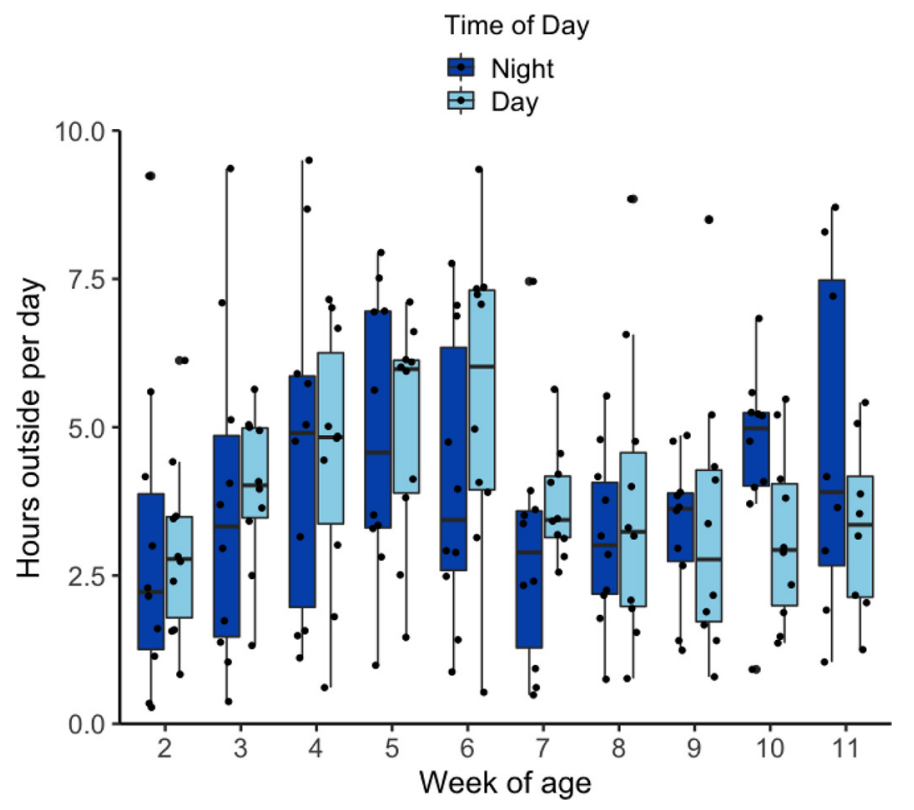

Figure 4. Average daily time (raw means) pairs of calves $(\mathrm{n}=10)$ spent outside during the day $(0600-2000 \mathrm{~h})$ or night $(2000-0600 \mathrm{~h})$ when they had free choice between the indoors $(3.66 \times 2.44 \mathrm{~m})$ and outdoors $(3.66 \times 2.44 \mathrm{~m})$. Calves increased their time spent outside during the day during the first $6 \mathrm{wk}$ of age, and then spent less time outside during the day from 7 to 11 wk of age $(P<0.04)$. Box plots show medians (horizontal line) and 25th and 75th percentiles (boundaries of the box or hinges; first and third quartiles). The upper whisker extends from the hinge to the largest value no further than 1.5 times the interquartile range. The lower whisker extends from the hinge to the smallest value at most 1.5 times the interquartile range. Data points on the graph are the means for each pair of calves.

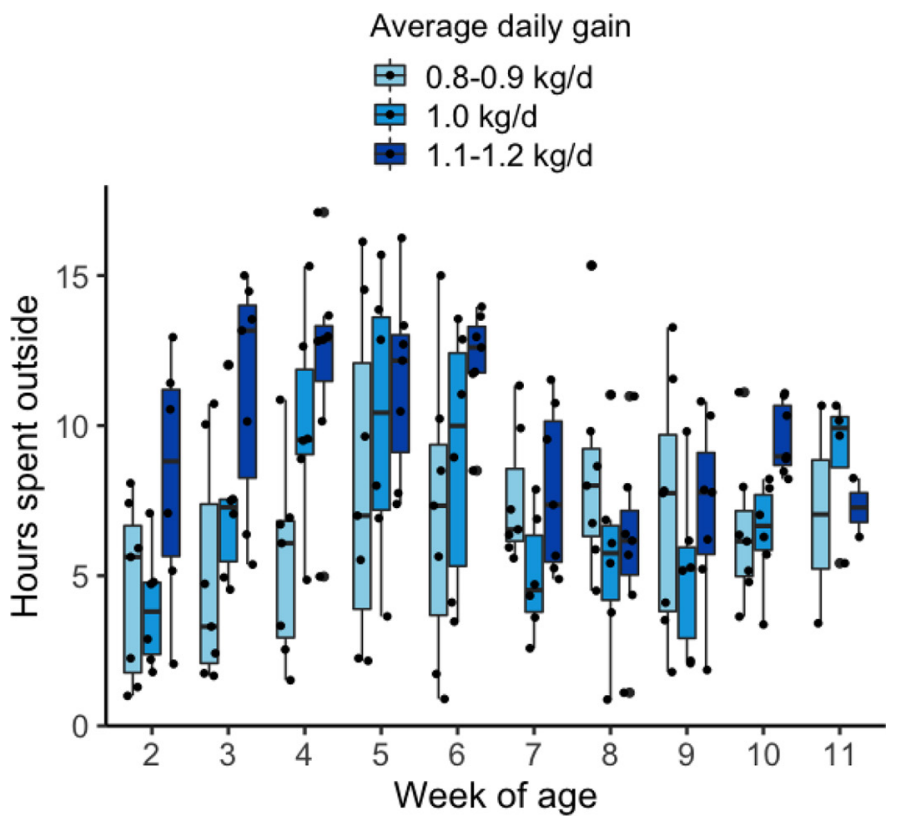

Figure 5. Average daily time (raw means) pairs of calves $(\mathrm{n}=10)$ spent outside throughout the day $(24 \mathrm{~h})$ when they had free choice between the indoors $(3.66 \times 2.44 \mathrm{~m})$ and outdoors $(3.66 \times 2.44 \mathrm{~m})$. Calves gaining $>1.0 \mathrm{~kg} / \mathrm{d}(\mathrm{n}=7)$ appeared to spend the most time outside compared with calves gaining $1.0 \mathrm{~kg} / \mathrm{d}(\mathrm{n}=6)$, or calves gaining $<1.0 \mathrm{~kg} / \mathrm{d}(\mathrm{n}=7)$. Box plots show medians (horizontal line) and 25th and 75th percentiles (boundaries of the box or hinges; first and third quartiles). The upper whisker extends from the hinge to the largest value no further than 1.5 times the interquartile range. The lower whisker extends from the hinge to the smallest value at most 1.5 times the interquartile range. Data points on the graph are the means for each pair of calves.

proportion of their time standing when they were outside and inside (Table 2).

\section{DISCUSSION}

Though the preferences of adult dairy cattle for outdoor spaces has received attention (Legrand et al., 2009; Charlton et al., 2011a; Smid et al., 2019), to our knowledge this is the first study to describe the preferences of calves for an outdoor space. This study highlights that, during their first 2 mo of life, calves spend approximately $30 \%$ of their time outdoors on bark mulch when given the opportunity. Similarly, Smid et al. (2019) found that adult cows spent $25 \%$ of their time outside on a bark mulch pack during summer. A few other studies have described higher proportions of time outside when cows are asked to choose between indoors and pasture (Legrand et al., 2009; Charlton et al., 2011b, 2013); future work may consider exploring calf preferences for pasture. Calves begin grazing in their first 2 wk of life (Noller et al., 1959; Dwyer, 1961; Hutchison et al., 1962), and grazing time increases with 
Table 2. Proportion of time pairs of calves $(n=10)$ spent standing when they were inside or outside during each of the experimental periods

\begin{tabular}{lcccccccc}
\hline & \multicolumn{3}{c}{ When outside: \% standing } & & \multicolumn{3}{c}{ When inside: \% standing } \\
\cline { 2 - 3 } \cline { 7 - 8 } Weaning period $^{1}$ & Mean & SD & Range & & Mean & SD & Range \\
\hline Preweaning & 45.9 & 21.4 & $17.5-87.3$ & & 29.5 & 7.6 & $19.7-40.1$ \\
Weaning & 37.6 & 12.6 & $16.0-65.8$ & & 35.0 & 7.3 & $22.4-48.5$ \\
Postweaning & 34.3 & 10.9 & $18.6-46.4$ & & 32.6 & & 4.7 & $24.3-38.2$ \\
\hline
\end{tabular}

${ }^{1}$ Preweaning (5-29 d of age: $8 \mathrm{~L} / \mathrm{d}$ ), weaning (30-55 d of age: milk gradually reduced by $1 \mathrm{~L} / \mathrm{d}$ from d $30-35$ so that calves were fed $6 \mathrm{~L} / \mathrm{d}$ until d 51 where milk was once again decreased by $1 \mathrm{~L} / \mathrm{d}$ for $5 \mathrm{~d}$ ), and postweaning (56-70 d of age: $0 \mathrm{~L} / \mathrm{d})$.

age (Chambers, 1959; Dwyer, 1961; Hutchison et al., 1962); thus, the proportion of time spent outside may be different if young calves have access to grass.

Though calves in our study spent more time inside, it is important to note that calves increased the time spent outside during the first 6 wk of life, and made use of the outdoor area during every week of the study period, including their first day in the experimental pens. The amount of time calves spent outdoors seemed to vary in relation to several factors. Several studies have described changing adult cow preferences for an outdoor space in different weather conditions during the summer. One study reported that cows tended to spend more time outside on an outdoor pack during the day on days with precipitation (Smid et al., 2019), and another study reported no effect of rain on preference for pasture (Charlton et al., 2011b). However, it appears that most studies suggest that rain, particularly at night (Legrand et al., 2009; Smid et al., 2019), decreases the amount of time cows spend outside (Charlton et al., 2011a, 2013). Similarly, we found that calves spent less time outside on days with rain. During our study, calves also showed some preference for shade. When calves were outside, calves spent similar amounts of time in both the sun and shade, but when indoors calves spent most of their time in the shade. It could be that there was less surface area indoors for the sun to shine on, though video observers did notice calves moving out of the sun as the sun shifted throughout the day. This result suggests that it is important for calves to be able to escape direct sunlight (and rainfall) as needed. Likewise, adult animals spend more time in shade on warmer days (Schütz et al., 2010), and will even choose shade instead of lying after experiencing some sleep deprivation (Schütz et al., 2008). For systems that raise calves outdoors, such as New Zealand (Cuttance et al., 2017) and Australia (Abuelo et al., 2019), providing access to shelter allows calves to show these environmental preferences.

Most calves spent less time outside during the milk feeding hours (0800 and $1800 \mathrm{~h}$ ) and appeared to use the outdoor space most during the evening hours
(1700-2100 h); this effect was most noticeable during preweaning. Additionally, calves in our study spent the greatest proportion of their time standing outdoors preweaning, though the proportion of time spent standing was similar inside and outside during weaning and postweaning. Other studies have reported that play behavior is most frequent during the calf's first month of age and then wanes with age (Espmark, 1971; Vitale et al., 1986; Jensen and Kyhn, 2000). Perhaps the outdoor space promoted active behaviors for the calves during preweaning that may have followed a diurnal pattern. Calves kept on pasture with a herd have been described to follow a diurnal activity pattern such that they peak in play during the evening hours (Dwyer, 1961; Espmark, 1971; Reinhardt and Reinhardt, 1981). The combined indoor and outdoor space in the experimental pen may have been conducive to locomotory play behaviors such as running. Calves prefer rooms with more space when given the choice in a T-maze (Jensen, 1999). In the home environment, 5 -wk old calves raised in group pens with more space performed more play behavior than calves in a smaller group pen (Jensen and Kyhn, 2000). Future studies could record behaviors in addition to standing and lying to better understand how calves use indoor and outdoor spaces.

Calves varied in when they used the outdoor space. One pair in particular used the outdoors during most of the day during the weaning and postweaning phases, although on average, calves decreased their time spent outside after 6 wk of age. Adult cows spend more time outside at night than during the day (Legrand et al., 2009; Charlton et al., 2013; Smid et al., 2019). Though we could not detect differences in time spent outside during the night as calves grew older, we encourage future work to follow calves beyond $70 \mathrm{~d}$ of age to see if there is a shift toward nighttime access for outdoor space. In our study, calves increased their time spent outside during the day during the first 6 wk of age, then decreased time outside during wk 6 to 10, during which time there was also a complete removal of milk at d 56. From wk 9 to 11, we could not detect statistical differences, but descriptively (Figure 4) calves might be 
increasing their time spent outside during the night. The stress of weaning may have contributed to these pattern shifts. Calves react to loss of milk by vocalizing and walking more, and ruminating less (Hötzel et al., 2010). When calves are weaned using a gradual method, they begin to consume increasing amounts of concentrates after their milk allowance is lowered (Khan et al., 2007; Rosenberger et al., 2017; Benetton et al., 2019). Calves often continue to visit the milk feeding area for some time after weaning, in an apparent attempt to access milk (de Passillé et al., 2011; Rosenberger et al., 2017; Benetton et al., 2019). During wk 7 to 10, calves in our study may have spent more time inside during the day if they were also continuing to visit the milk feeding area despite being weaned. We did not measure this behavior, or concentrate intake or time spent eating concentrates, and recommend that future studies include these measures to better understand why calves decrease their time spent outdoors around weaning.

There may have been calf level factors that also affected the time each calf spent outside. For example, coat color may have contributed to calf preference for an outdoor space, but our data were limited. A few studies have reported that white cows absorb less heat than black cows (Finch and Western, 1977; Campos Maia et al., 2005) so future studies should include coat color when assessing calf preference for the outdoors. Additionally, calves with the highest ADG appear to spend the most time outside. Perhaps calves varied when they began eating concentrates (Roth et al., 2009), which led to differences in growth (de Passillé and Rushen, 2016; Benetton et al., 2019) or metabolism. Future studies may consider including individual physiological measures in addition to concentrate intake to better understand how individuals experience temperature indoors and outdoors.

Our study had several limitations. We collected our observations during a mild summer in British Columbia's lower Fraser valley; calves may have different preferences in different climatic conditions. For example, heat stress can result in decreased feed intake, increased respiration rate, and changes in rumen motility (reviewed by Wang et al., 2020); higher THI during the day decreases the time adult cows spend on pasture (Legrand et al., 2009). We recommend that future studies continue to include THI as a metric, as more severe weather conditions may affect a calf's preference for an outdoor space. Second, we only measured standing and lying behaviors, and did not describe the full suite of behaviors calves perform. Future studies should consider capturing exploration, play, feeding, and rumination. Feed intake and rumination may also help explain individual differences in heat tolerance between calves.

\section{CONCLUSIONS}

During the mild summer conditions of this study, calves spent increasing amounts of time outside during the day during their first 6 wk of life, but time outside decreased around weaning and postweaning. Calves spent approximately one-third of their time outside; choice was affected by daily rainfall. Before weaning calves appeared to use the outdoor space for active behaviors, and throughout the study, the indoor area appeared to be used for shade and shelter.

\section{ACKNOWLEDGMENTS}

Thank you to the staff and students of the University of British Columbia Animal Welfare Program (Vancouver, Canada) and the University of British Columbia Dairy Education and Research Centre (Agassiz, Canada), particularly Cady Chan, Philippine Coeugnet, Thomas Ede, Brynn McLellan, Kathryn McLellan, Marisol Ortiz, and Megan Whalin, for invaluable assistance with project setup and data collection. In addition, we thank Agriculture and Agri-Food Canada (Agassiz, BC, Canada) for providing us access to the hourly weather data. Funding for LW was provided by the UBC Four Year Doctoral Fellowship. General funding for UBC's Animal Welfare Program comes from an NSERC Industrial Research Chair with industry contributions from the Dairy Farmers of Canada (Ottawa, ON, Canada), Saputo Inc. (Montréal, QC, Canada), British Columbia Dairy Association (Burnaby, BC Canada), Alberta Milk (Edmonton, AB, Canada), Intervet Canada Corporation (Kirkland, QC, Canada), Boehringer Ingelheim Animal Health (Burlington, ON, Canada), BC Cattle Industry Development Fund (Kamloops, BC, Canada), The Semex Alliance (Guelph, ON, Canada), CanWest DHI (Guelph, ON, Canada), Dairy Farmers of Manitoba (Winnipeg, MB, Canada), and the Saskatchewan Milk Marketing Board (Regina, SK, Canada). The authors have not stated any conflicts of interest.

\section{REFERENCES}

Abuelo, A., P. Havrlant, N. Wood, and M. Hernandez-Jover. 2019. An investigation of dairy calf management practices, colostrum quality, failure of transfer of passive immunity, and occurrence of enteropathogens among Australian dairy farms. J. Dairy Sci. 102:8352-8366. https://doi.org/10.3168/jds.2019-16578.

Benetton, J. B., H. W. Neave, J. H. C. Costa, M. A. G. von Keyserlingk, and D. M. Weary. 2019. Automatic weaning based on individual solid feed intake: Effects on behavior and performance of dairy calves. J. Dairy Sci. 102:5475-5491. https://doi.org/10 .3168/jds.2018-15830.

Broucek, J., M. Uhrincat, P. Kisac, and A. Hanus. 2021. The effect of rearing conditions during the milk-fed period on milk yield, 
growth, and maze behaviour of dairy cows during their first lactation. Arch. Anim. Breed. 64:69-82. https://doi.org/10.5194/aab -64-69-2021.

Campos Maia, A. S., R. Gomes da Silva, and E. C. Abaker Bertipaglia. 2005. Environmental and genetic variation of the effective radiative properties of the coat of Holstein cows under tropical conditions. Livest. Prod. Sci. 92:307-315. https://doi.org/10.1016/ j.livprodsci.2004.09.004.

Cardoso, C. S., M. J. Hötzel, D. M. Weary, J. A. Robbins, and M. A. G. von Keyserlingk. 2016. Imagining the ideal dairy farm. J. Dairy Sci. 99:1663-1671. https://doi.org/10.3168/jds.2015-9925.

Chambers, D. T. 1959. Grazing behaviour of calves reared at pasture. J. Agric. Sci. 53:417-424. https://doi.org/10.1017/ S0021859600020840.

Charlton, G. L., and S. M. Rutter. 2017. The behaviour of housed dairy cattle with and without pasture access: A review. Appl. Anim. Behav. Sci. 192:2-9. https://doi.org/10.1016/j.applanim .2017.05.015.

Charlton, G. L., S. M. Rutter, M. East, and L. A. Sinclair. 2011a. Preference of dairy cows: Indoor cubicle housing with access to a total mixed ration vs. access to pasture. Appl. Anim. Behav. Sci. 130:1-9. https://doi.org/10.1016/j.applanim.2010.11.018.

Charlton, G. L., S. M. Rutter, M. East, and L. A. Sinclair. 2011b. Effects of providing total mixed rations indoors and on pasture on the behavior of lactating dairy cattle and their preference to be indoors or on pasture. J. Dairy Sci. 94:3875-3884. https://doi.org/ 10.3168/jds.2011-4172.

Charlton, G. L., S. M. Rutter, M. East, and L. A. Sinclair. 2013. The motivation of dairy cows for access to pasture. J. Dairy Sci. 96:4387-4396. https://doi.org/10.3168/jds.2012-6421.

Costa, J. H. C., R. R. Daros, M. A. G. von Keyserlingk, and D. M. Weary. 2014. Complex social housing reduces food neophobia in dairy calves. J. Dairy Sci. 97:7804-7810. https://doi.org/10.3168/ jds.2014-8392.

Cuttance, E. L., W. A. Mason, J. McDermott, R. A. Laven, S. McDougall, and C. V. C. Phyn. 2017. Calf and replacement heifer mortality from birth until weaning in pasture-based dairy herds in New Zealand. J. Dairy Sci. 100:8347-8357. https://doi.org/10 .3168/jds.2017-12793.

de Passillé, A. M., T. F. Borderas, and J. Rushen. 2011. Weaning age of calves fed a high milk allowance by automated feeders: Effects on feed, water, and energy intake, behavioral signs of hunger, and weight gains. J. Dairy Sci. 94:1401-1408. https://doi.org/10.3168/ jds.2010-3441.

de Passillé, A. M., and J. Rushen. 2016. Using automated feeders to wean calves fed large amounts of milk according to their ability to eat solid feed. J. Dairy Sci. 99:3578-3583. https://doi.org/10 $.3168 /$ jds.2015-10259

De Paula Vieira, A., A. M. de Passillé, and D. M. Weary. 2012. Effects of the early social environment on behavioral responses of dairy calves to novel events. J. Dairy Sci. 95:5149-5155. https://doi.org/ $10.3168 /$ jds.2011-5073.

Duve, L. R., D. M. Weary, U. Halekoh, and M. B. Jensen. 2012. The effects of social contact and milk allowance on responses to handling, play, and social behavior in young dairy calves. J. Dairy Sci. 95:6571-6581. https://doi.org/10.3168/jds.2011-5170.

Dwyer, D.D. 1961. Activities and grazing preferences of cows with calves in northern Osage Country, Oklahoma. Oklahoma Agricultural Experiment Station.

Espmark, Y. 1971. Mother-young relationship and ontogeny of behaviour in reindeer (Rangifer tarandus L.). Z. Tierpsychol. 29:42-81. https://doi.org/10.1111/j.1439-0310.1971.tb01723.x.

Fecteau, G., J. Paré, D. C. Van Metre, B. P. Smith, C. A. Holmberg, W. Guterbock, and S. Jang. 1997. Use of a clinical sepsis score for predicting bacteremia in neonatal dairy calves on a calf rearing farm. Can. Vet. J. 38:101-104.

Finch, V. A., and D. Western. 1977. Cattle colors in pastoral herds: Natural selection or social preference? Ecology 58:1384-1392. https://doi.org/10.2307/1935090.
Firke, S. 2021. janitor: Simple tools for examining and cleaning dirty data. R package version 2.1.0. Accessed Jul. 15, 2021. https:// CRAN.R-project.org/package=janitor.

Fraser, D., D. Weary, E. A. Pajor, and B. N. Milligan. 1997. A scientific conception of animal welfare that reflects ethical concerns. Anim. Welf. 6:187-205.

Gaillard, C., R. K. Meagher, M. A. G. von Keyserlingk, and D. M. Weary. 2014. Social housing improves dairy calves' performance in two cognitive tests. PLoS One 9:e90205. https://doi.org/10.1371/ journal.pone.0090205.

Grolemund, G., and H. Wickham. 2011. Dates and times made easy with lubridate. J. Stat. Softw. 40:1-25. https://doi.org/10.18637/ jss.v040.i03.

Hötzel, M. J., C. S. Cardoso, A. Roslindo, and M. A. G. von Keyserlingk. 2017. Citizens' views on the practices of zero-grazing and cow-calf separation in the dairy industry: Does providing information increase acceptability? J. Dairy Sci. 100:4150-4160. https:// doi.org/10.3168/jds.2016-11933.

Hötzel, M. J., R. Ungerfeld, and G. Quintans. 2010. Behavioural responses of 6-month-old beef calves prevented from suckling: Influence of dams milk yield. Anim. Prod. Sci. 50:909-915. https://doi .org/10.1071/AN09136.

Hutchison, H. G., R. Woof, R. M. Mabon, I. Salehe, and J. M. Robb. 1962. A study of the habits of zebu cattle in Tanganyika. J. Agric Sci. 59:301-317. https://doi.org/10.1017/S0021859600015379.

Jensen, M. B. 1999. Effects of confinement on rebounds of locomotor behaviour of calves and heifers, and the spatial preferences of calves. Appl. Anim. Behav. Sci. 62:43-56. https://doi.org/10 .1016/S0168-1591(98)00208-1.

Jensen, M. B., and R. Kyhn. 2000. Play behaviour in group-housed dairy calves, the effect of space allowance. Appl. Anim. Behav. Sci. 67:35-46. https://doi.org/10.1016/S0168-1591(99)00113-6.

Jensen, M. B., K. S. Vestergaard, C. C. Krohn, and L. Munksgaard. 1997. Effect of single versus group housing and space allowance on responses of calves during open-field tests. Appl. Anim. Behav. Sci. 54:109-121. https://doi.org/10.1016/S0168-1591(96)01183-5.

Kassambara, A. 2020. ggpubr: "ggplot2" based publication ready plots. R package version 0.4.0. Accessed Mar. 5, 2021. https://CRAN.R -project.org $/$ package $=$ ggpubr.

Kerr, S. G. C., and D. G. M. Wood-Gush. 1987. A comparison of the early behaviour of intensively and extensively reared calves. Anim. Sci. 45:181-190. https://doi.org/10.1017/S0003356100018778.

Khan, M. A., H. J. Lee, W. S. Lee, H. S. Kim, S. B. Kim, K. S. Ki, J. K. Ha, H. G. Lee, and Y. J. Choi. 2007. Pre- and postweaning performance of Holstein female calves fed milk through step-down and conventional methods. J. Dairy Sci. 90:876-885. https://doi .org/10.3168/jds.S0022-0302(07)71571-0.

Kilgour, R. J., K. Uetake, T. Ishiwata, and G. J. Melville. 2012. The behaviour of beef cattle at pasture. Appl. Anim. Behav. Sci. 138:12-17. https://doi.org/10.1016/j.applanim.2011.12.001.

Kirkden, R. D., and E. A. Pajor. 2006. Using preference, motivation and aversion tests to ask scientific questions about animals' feelings. Appl. Anim. Behav. Sci. 100:29-47. https://doi.org/10.1016/ j.applanim.2006.04.009.

Lassen, J., P. Sandøe, and B. Forkman. 2006. Happy pigs are dirty! - Conflicting perspectives on animal welfare. Livest. Sci. 103:221230. https://doi.org/10.1016/j.livsci.2006.05.008.

Legrand, A. L., M. A. G. von Keyserlingk, and D. M. Weary. 2009. Preference and usage of pasture versus free-stall housing by lactating dairy cattle. J. Dairy Sci. 92:3651-3658. https://doi.org/10 $.3168 /$ jds.2008-1733.

Martins, L. S., M. F. Paulino, L. N. Rennó, E. Detmann, D. M. de Almeida, R. M. Ortega, D. P. S. Moreno, and J. E. G. Cárdenas. 2017. Creep feeding effects on male Nellore calves influencing behavior and performance of their dams. Trop. Anim. Health Prod. 49:1669-1676. https://doi.org/10.1007/s11250-017-1375-8.

McGuirk, S. M. 2008. Disease management of dairy calves and heifers. Vet. Clin. North Am. Food Anim. Pract. 24:139-153. https://doi .org/10.1016/j.cvfa.2007.10.003. 
McGuirk, S. M., and S. F. Peek. 2014. Timely diagnosis of dairy calf respiratory disease using a standardized scoring system. Anim. Health Res. Rev. 15:145-147. https://doi.org/10.1017/ S1466252314000267.

Meagher, R. K., R. R. Daros, J. H. C. Costa, M. A. G. von Keyserlingk, M. J. Hötzel, and D. M. Weary. 2015. Effects of degree and timing of social housing on reversal learning and response to novel objects in dairy calves. PLoS One 10:e0132828. https://doi.org/10 1371/journal.pone.0132828.

Müller, K. 2021. hms: Pretty time of day. R package version 1.1.0. Accessed Jul. 1, 2021. https://CRAN.R-project.org/package=hms.

Noller, C. H., M. C. Stillions, B. W. Crowl, N. S. Lundquist, and A. L. Delez. 1959. Pasture for young dairy calves. J. Dairy Sci. 42:15921599. https://doi.org/10.3168/jds.S0022-0302(59)90771-4.

Ooms, J. 2020. writexl: Export data frames to Excel "xlsx" format. R package version 1.3.1. Accessed Jul. 1, 2021. https://cran.r-project . org $/$ package $=$ writexl.

Pempek, J. A., M. L. Eastridge, and K. L. Proudfoot. 2017. The effect of a furnished individual hutch pre-weaning on calf behavior, response to novelty, and growth. J. Dairy Sci. 100:4807-4817. https: //doi.org/10.3168/jds.2016-12180.

R Core Team. 2018. R: A Language and Environment for Statistical Computing. R Foundation for Statistical Computing. https://www R-project.org/.

Ravagnolo, O., I. Misztal, and G. Hoogenboom. 2000. Genetic component of heat stress in dairy cattle, development of heat index function. J. Dairy Sci. 83:2120-2125. https://doi.org/10.3168/jds S0022-0302(00)75094-6.

Reinhardt, V., and A. Reinhardt. 1981. Natural sucking performance and age of weaning in zebu cattle (Bos indicus). J. Agric. Sci. 96:309-312. https://doi.org/10.1017/S0021859600066089.

Renaud, D. L., T. F. Duffield, S. J. LeBlanc, D. B. Haley, and D. F. Kelton. 2018. Clinical and metabolic indicators associated with early mortality at a milk-fed veal facility: A prospective case-control study. J. Dairy Sci. 101:2669-2678. https://doi.org/10.3168/ jds.2017-14042.

Rosenberger, K., J. H. C. Costa, H. W. Neave, M. A. G. von Keyserlingk, and D. M. Weary. 2017. The effect of milk allowance on behavior and weight gains in dairy calves. J. Dairy Sci. 100:504-512. https://doi.org/10.3168/jds.2016-11195.

Roth, B. A., N. M. Keil, L. Gygax, and E. Hillmann. 2009. Influence of weaning method on health status and rumen development in dairy calves. J. Dairy Sci. 92:645-656. https://doi.org/10.3168/ jds.2008-1153.

Sato, P., M. J. Hötzel, and M. A. G. von Keyserlingk. 2017. American citizens' views of an ideal pig farm. Animals (Basel) 7:64. https:// doi.org/10.3390/ani7080064.

Schuppli, C. A., M. A. G. von Keyserlingk, and D. M. Weary. 2014. Access to pasture for dairy cows: Responses from an online engagement. J. Anim. Sci. 92:5185-5192. https://doi.org/10.2527/ jas.2014-7725.

Schütz, K. E., N. R. Cox, and L. R. Matthews. 2008. How important is shade to dairy cattle? Choice between shade or lying following different levels of lying deprivation. Appl. Anim. Behav. Sci. 114:307-318. https://doi.org/10.1016/j.applanim.2008.04.001.

Schütz, K. E., A. R. Rogers, Y. A. Poulouin, N. R. Cox, and C. B. Tucker. 2010. The amount of shade influences the behavior and physiology of dairy cattle. J. Dairy Sci. 93:125-133. https://doi .org/10.3168/jds.2009-2416.

Smid, A. M. C., E. E. A. Burgers, D. M. Weary, E. A. M. Bokkers, and M. A. G. von Keyserlingk. 2019. Dairy cow preference for access to an outdoor pack in summer and winter. J. Dairy Sci. 102:1551-1558. https://doi.org/10.3168/jds.2018-15007.

Smid, A.-M. C., D. M. Weary, J. H. C. Costa, and M. A. G. von Keyserlingk. 2018. Dairy cow preference for different types of outdoor access. J. Dairy Sci. 101:1448-1455. https://doi.org/10.3168/jds $.2017-13294$

Smid, A.-M. C., D. M. Weary, and M. A. G. von Keyserlingk. 2020. The influence of different types of outdoor access on dairy cattle behavior. Front. Vet. Sci. 7:257. https://doi.org/10.3389/fvets .2020 .00257

Te Velde, H., N. Aarts, and C. Van Woerkum. 2002. Dealing with ambivalence: Farmers' and consumers' perceptions of animal welfare in livestock breeding. J. Agric. Environ. Ethics 15:203-219. https: //doi.org/10.1023/A:1015012403331.

Vanhonacker, F., W. Verbeke, E. Van Poucke, and F. A. M. Tuyttens. 2008. Do citizens and farmers interpret the concept of farm animal welfare differently? Livest. Sci. 116:126-136. https://doi.org/10 $.1016 / j$.livsci.2007.09.017.

Vitale, A. F., M. Tenucci, M. Papini, and S. Lovari. 1986. Social behaviour of the calves of semi-wild Maremma cattle, Bos primigenius taurus. Appl. Anim. Behav. Sci. 16:217-231. https://doi.org/ 10.1016/0168-1591(86)90115-2.

Wang, J., J. Li, F. Wang, J. Xiao, Y. Wang, H. Yang, S. Li, and Z Cao. 2020. Heat stress on calves and heifers: A review. J. Anim. Sci. Biotechnol. 11:79. https://doi.org/10.1186/s40104-020-00485 -8 .

Wickham, H. 2011. The split-apply-combine strategy for data. J. Stat. Softw. 40:1-29. https://doi.org/10.18637/jss.v040.i01.

Wickham, H., M. Averick, J. Bryan, W. Chang, L. D'Agostino McGowan, R. François, G. Grolemund, A. Hayes, L. Henry, J. Hester, M. Kuhn, T. L. Pedersen, E. Miller, S. M. Bache, K. Müller, J. Ooms, D. Robinson, D. P. Seidel, V. Spinu, K. Takahashi, D. Vaughan, C. Wilke, K. Woo, and H. Yutani. 2019. Welcome to the tidyverse. J. Open Source Softw. 4:1686. https://doi.org/10.21105/ joss.01686.

Wilson, D. J., J. Stojkov, D. L. Renaud, and D. Fraser. 2020. Short communication: Condition of male dairy calves at auction markets. J. Dairy Sci. 103:8530-8534. https://doi.org/10.3168/jds 2019-17860.

Zobel, G., H. W. Neave, H. V. Henderson, and J. Webster. 2017. Use an automated brush and a hanging rope when pair-housed. Animals (Basel) 7:84. https://doi.org/10.3390/ani7110084.

\section{ORCIDS}

Laura Whalin (๑ https://orcid.org/0000-0001-8710-4993

Daniel M. Weary ๑ https://orcid.org/0000-0002-0917-3982

Marina A. G. von Keyserlingk (1) https://orcid.org/0000-0002-1427 $-3152$ 